\title{
AUTHOR'S PREFACE
}

HE STORY of the old Franciscan missions of California, which bad their beginning in 1769 at San Diego under 1 the eye and hand of Fray Junipero Serra, is well known; they are justly renowned for the bistorical importance of their permanence, for the color they lend to California's past, and for their picturesque ruins which add to the romantic atmosphere of the State. It is not so widely known, however, that they were but the last link in a long chain of cultural and bumanitarian foundations for the North American native, a chain the first link of which was forged by men who bad begun their labors far soutb of the California frontier, two centuries before. The first permanent missionaries nortb of Culiacán on the west coast of North America were Jesuit Black Robes, and of these the two earliest pioneers were Gonzalo de Tapia and Martín Pérez. They began their labor of Cbristianizing the natives in 1591 on the Sinaloa River in Mexico, not far from the moutb of the Gulf of California.

The present work intends to tell the story of the Jesuit missionary undertaking, but only during the first four decades, from $159^{1}$ to $1632-$ which will suffice to show the western missions well on the way toward their march to San Francisco.

The author of the present work is grateful to many who bave inspired and aided bim in his task. To Dr. Herbert Eugene Bolton, under whose direction these studies were begun some years ago, who bas been the chief inspiration of all that is bere set down, and who assembled most of the source materials used, be owes a special debt of gratitude. Iesuit superiors, by releasing the author from other duties, belped to make the work possible in the first instance, and have continued to further it by their interest and encouragement. Jesuit confreres of the Province of 
Mexico bave given valuable assistance by lending documents and by facilitating a review of the geographical terrain. Generous aid and service bave been rendered by the staff of the Bancroft Library at the University of California, and by those who at the expense of much labor and devotion have copied and recopied the manuscript and have aided in the reading of the proofs.

P. M. D.

Department of History,

University of San Francisco,

March 1,1940 . 